\title{
Magnetic susceptibility and biotite composition of granitoids of Amritpur and adjoining regions, Kumaun Lesser Himalaya
}

\author{
Santosh Kumar*, Brajesh Singh, CC J oshi and Abhishek Pandey \\ Department of Geology, Kumaun University, Nainital 263 002, Uttaranchal, INDIA \\ * To whom correspondence should beaddressed. E-mail: skyadavan@yahoo.com
}

Felsic magmatism in Amritpur and adjoining localities of Kumaun Lesser Himalaya is represented by Palaeoproterozoic ( $-1890 \mathrm{Ma})$ Bt-Ms granitoids and quartz feldspar porphyries, referred to as Amritpur granitoids (AG) and Amritpur porphyry (AP) respectively. The AG are porphyritic and equigranular as well, and extend from Suraijula (west) to Barhoan (east) in the Nainital district of Kumaun Lesser Himalaya. The Main Boundary Thrust (MBT) forms the southern boundary of AG, and quartzite-metabasalts association is exposed in the north. The equigranular variety of $A G$, referred to as Amritpur leucogranite (ALG) dominates over porphyritic ones, and is medium- to coarse-grained, hypidiomorphic, mainly composed of K-feldspar (perthite), quartz and plagioclase (sericite). Muscovite is present associated with biotite but varies in proportion ranging from rare to noticeable amount. The magnetic susceptibility (MS) measurements of AP and AG were carried out in thefield on smooth rock surfaces using hand-held SM-20 magnetic susceptibility meter. The obtained MS value (SI unit) was further corrected according to the degree of the rock-surface unevenness. Primary biotites from ALG were analyzed by wavelength dispersive electron-probe microanalysis. Ferrous and ferric iron from total iron (FeO) of biotite was estimated following charge-balance procedures.

The MS values of AP vary from 0.399 to $0.912 \times 10^{-3} \mathrm{SI}$ unit with an average of $0.528 \times 10^{-3} \mathrm{SI}(\mathrm{N}=17)$, which typicallyrepresent ilmenite series $\left(\chi \leq 3.0 \times 10^{-3} \mathrm{SI}\right)$ granite (Ishihara 1977). Mediumgrained ALG measures relatively lesser MS values $(\chi=0.003$ $\left.0.148 \times 10^{-3} \mathrm{SI}\right)$ with an average of $0.062 \times 10^{-3} \mathrm{SI}(\mathrm{N}=55)$ compared to coarse-grained ALG which vary from 0.025 to $0.195 \times 10^{3} \mathrm{SI}$ with an average $\mathrm{MS}$ of $0.117 \times 10^{-3} \mathrm{SI}(\mathrm{N}=18)$, both being related to ilmenite series granite. Coarse-grained gneissic AG, exposed at places, record the MS values ranging from 0.295 to $0.527 \times 10^{-3}$ $\mathrm{SI}$ with an average $\mathrm{MS}$ value of $0.379 \times 10^{-3} \mathrm{SI}(\mathrm{N}=26)$. Porphyritic $A G$, an older lithounit, are xenolith-bearing and xenolith-free, and their MS values range from 0.368 to $0.629 \times 10^{-3} \mathrm{SI}$ and from 0.142 to $0.247 \times 10^{-3} \mathrm{SI}$ with average $\mathrm{MS}$ of $0.522 \times 10^{-3} \mathrm{SI}(\mathrm{N}=10)$ and $0.190 \times 10^{-3} \mathrm{SI}(\mathrm{N}=10)$ respectively. The observed MS variations of porphyritic AG appear related with xenolith incorporation, which might have slightly oxidized the porphyritic AG. The MS values of AP and AG including the ALG typically correspond to ilmenite series granites, and the noted MS variations may be related with their differing contents of ferromagnesian minerals, ilmenite and textural variations. The AG including the ALG are typically peraluminous (S-type) consistent with their nature similar to ilmenite series granites. About $60 \%$ of whole-rock data $(N=13)$ of AP (Gupta et al. 1994; Nautiyal and Rawat 1990) are metaluminous (I-type) despite of their exclusively ilmenite series nature. In Japan nearly all the ilmenite series are I-type, and it has been observed that magnetite-/ilmenite-series classification is not exactly equivalent to the I-/S-type classification in terms of alumina saturation index (ASI).

The ALG biotites have $\Sigma$ X variation between 1.02 and 1.25 atoms in their structural formulae, which are dominantly

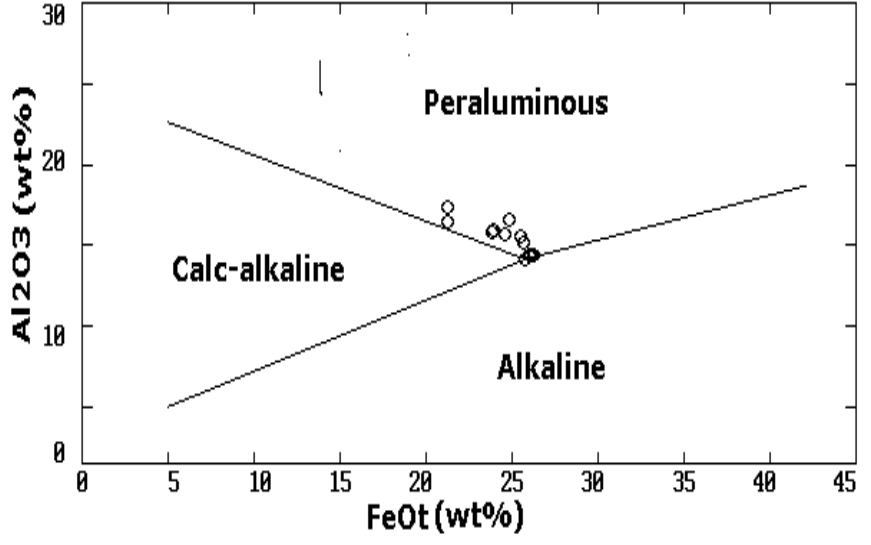

FIGURE 1. Bivariate $\mathrm{Al}_{2} \mathrm{O}_{3}$ vs. FeOt plot for biotite(0) hosted in $\mathrm{ALG}$. Biotites from ALG mostly plot in the field of biotites crystallizing in peraluminous (S-type) felsic magma. Fields are taken from AbdelRahman (1994)

contributed by potassium. The observed $\Sigma X$ values more than one in ALG biotites may be due to the replacement of $K$ by the elements $\mathrm{Ba}, \mathrm{Rb}$ and $\mathrm{Cs}$. Biotites of ALG plot into the field of primary biotite crystallized in felsic magma but scatter at and above the $\mathrm{Ni}-\mathrm{NiO}$ buffer. However, presence of ilmenite and substantially low MSvalues $\left(0.003-0.157 \times 10^{-3} \mathrm{SI}\right)$ of ALG suggest the prevalence of elevated reducing conditions during the evolution of ALG magma. The ALG melt was further reduced at emplacement level as evident by the presence of graphite pods and patches hosted in the ALG near the contact with countryrocks. The biotites of ALG areferri-biotites showing enrichment in siderophyllite component, which is commonly available in crustally-derived felsic melt. The ALG biotites in terms of MgO$\mathrm{FeO}^{\mathrm{t}} \mathrm{Al}_{2} \mathrm{O}_{3}$ components show the compositional similarity with the biotites unaccompanied with ferromagnesian minerals, which further suggest their crystallization in crustally-derived felsic magma. The $\mathrm{FeO} / \mathrm{MgO}$ ratio of biotite from ALG varies from 2.93 to 4.94 with an average of 4.00 suggesting the nature of host ALG magma similar to peraluminous (S-type) melt (Abdel-Rahman 1994). Biotites in ALG magma exhibit a negative $\mathrm{FeO}-\mathrm{Al}_{2} \mathrm{O}_{3}$ correlation (Figure 1) suggesting dominance of 3Fe 2Al substitution in producing Al-rich biotites, but the substitution of $3 \mathrm{Mg}-2 \mathrm{Al}$ mostly vital in calc-alkaline and peraluminous magma system cannot be unambiguously inferred.

Japanese and many other granitoids are emperically divided into magnetite and ilmenite series granites using bulk $\mathrm{Fe}_{2} \mathrm{O}_{3}$ (wt\%) / $\mathrm{FeO}$ (wt\%) ratio of 0.5 at $\mathrm{SiO}_{2}$ content of 70 wt\%; $\mathrm{Fe}_{2} \mathrm{O}_{3} / \mathrm{FeO}>0.5$ magnetiteseries, $\mathrm{Fe}_{2} \mathrm{O}_{3} / \mathrm{FeO}<0.5$ ilmeniteseries (Ishihara 1979). Bulk $\mathrm{Fe}_{2} \mathrm{O}_{3} / \mathrm{FeO}$ ratio of $\mathrm{AP}(\mathrm{N}=13)$ indicates proportion of 6:7 for magnetite to ilmenite-series in the silica 
range of 59.82 to $75.37 \mathrm{wt} \%$, suggesting that ilmeniteseries more or-less equals the magnetite series for AP. On the other hand $\mathrm{Fe}_{2} \mathrm{O}_{3} / \mathrm{FeO}$ ratio of $\mathrm{AG}(\mathrm{N}=17)$ varies from 0.01 to 0.18 except one sample $\left(\mathrm{Fe}_{2} \mathrm{O}_{3} / \mathrm{FeO}=0.87\right)$ in the $\mathrm{SiO}_{2}$ range of 67.08 to 78.74 wt $\%$, which indicates that most AG are ilmenite series granites and are in accordance with the observed MS values. IImenite series nature of AG is consistent with their peraluminous(S-type) nature, whereas AP represents both peraluminous (S-type) and metaluminous (I-type) as well. Biotite compositions from ALG suggest their evolution and stability in peraluminous (S-type) felsic melt, and henceit can be concluded that the ALG magma is essentially derived by the partial melting of crustal protolith (metapelite), which subsequently evolved under reducing environment most likely prevailed during pre-Himalayan syntectonic orogeny.

\section{References}

Abdel-Rahman, AM. 1994. Nature of biotites from alkaline, calc-alkaline and peraluminous magmas. J Petrol 35: 525-541

Gupta LN, Himanshu Ghildiyal and HS Chawla. 1994. Petrochemistry and tectonic environment of granites and porphyries of Amritpur-Ramgarh areas, Lesser Himalaya, Uttar Pradesh. J Himalayan Geol 5: 103116

Ishihara S. 1977. The magnetite-series and ilmenite-series granitic rocks. Min Geol 27: 293-305

IshiharaS. 1979. Lateral variation of magnetic susceptibility of theJapanese granitoids. J Geol Soc Japan 85: 509-523

Nautiyal SP and RS Rawat. 1990. Nature and preliminary petrochemistry of the Amritpur granites, Nainital district, Kumaun Himalaya, U.P., India. J Himalayan Geol 1: 199-208 